\title{
Coreid Bug, Leaf-footed Bug, Euthochtha galeator (Fabricius) (Insecta: Hemiptera: Coreidae) ${ }^{1}$
}

Frank W. Mead ${ }^{2}$

\section{Introduction}

The coreid bug, Euthochtha galeator (Fabricius), is common throughout the eastern United States west to the Great Plains (Slater and Baranowski 1978). The Florida State Collection of Arthropods (FSCA) contains numerous specimens and reports ranging from the northwestern tip of Florida to Key West. It feeds on a variety of wild and cultivated plants, occasionally becoming a pest primarily in dooryard situations where it can injure roses, citrus, and other fruits and ornamentals.

\section{Description and Identification}

\section{Eggs}

Yonke and Medler (1969b) reported the egg as $1.84 \times 1.20 \times 1.23 \mathrm{~mm}$ (mean value), roughly triangular in cross-section, and flattened on the underside. Eggs sometimes are whitish but usually are a bright gold color turning to bright red just before eclosion. Eggs usually are laid in small patches on either surface of a leaf but sometimes are laid in a row on a linear host such as a grass blade. Yonke and

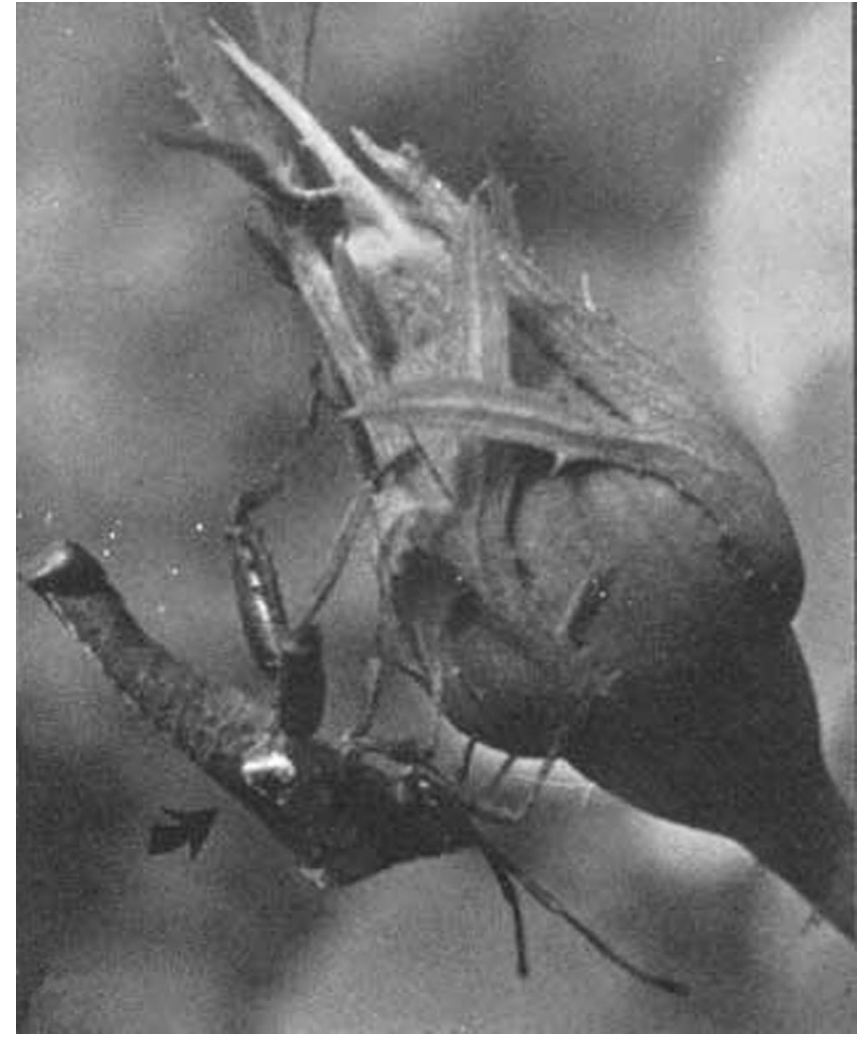

Figure 1. Adult Euthochtha galeator (Fabricius), a leaf-footed bug, feeding on rose bud. Credits: Division of Plant Industry

1. This document is EENY-293 (originally published as DPI Entomology Circular 222), one of a series of Featured Creatures from the Entomology and Nematology Department, Florida Cooperative Extension Service, Institute of Food and Agricultural Sciences, University of Florida. Published: June 2003. This document is also available on Featured Creatures Website at http://creatures.ifas.ufl.edu. Please visit the EDIS Website at http://edis.ifas.ufl.edu. Additional information on these organisms, including many color photographs, is available at the Entomology and Nematology Department website at http://entnemdept.ifas.ufl.edu/.

2. Frank W. Mead, Florida Department of Agriculture and Consumer Services, Division of Plant Industry, Gainesville. 
Medler (1969a) reported a range of two to $32 \mathrm{eggs}$ per batch, the mean number being 16 eggs/batch. The number of batches per female ranged from three to 19 , with the mean number being 8.2. The greatest number of eggs deposited by a single female was 259 .

\section{Nymphs}

Early instar nymphs tend to be purplish or reddish brown with orange heads. Older nymphs are variable but tend to be orange to yellowish brown, with the head mottled. All five instars are characterized by spines, mottling, and a dilated 3rd antennal segment. This is the only coreid nymph in eastern U.S. having the 3rd antennal segment (only) dilated. Nymphs of the coreids Chariesterus antennator (Fabricius) and Chondrocera latifornis LaPorte have both the 2nd and 3rd segments dilated; this expansion may not be as pronounced in the 2nd segment of early instar nymphs. The dilation of the antennae continues in adults as a partially expanded 3rd segment in Chariesterus and dilated 2nd and 3rd segments in Chondrocera; however, no segments of the adult of Euthochtha are dilated, all having a similar filiform shape, with the terminal segment usually being darker.

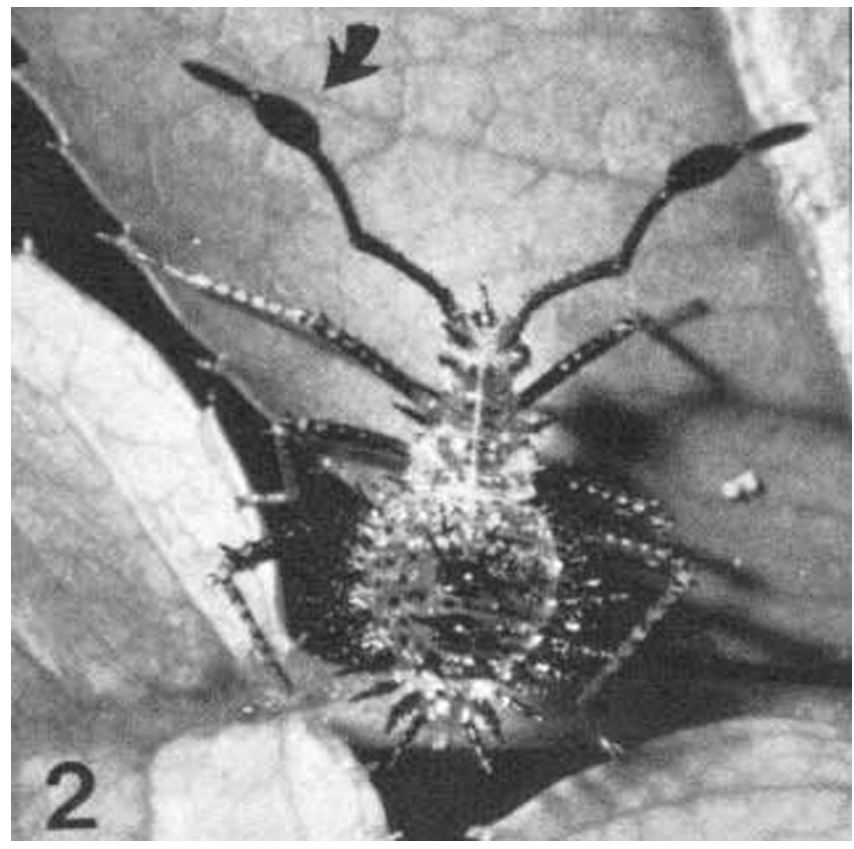

Figure 2. Nymph of Euthochtha galeator (Fabricius), a leaf-footed bug, showing the dilated 3rd antennal segment. Credits: Division of Plant Industry

\section{Adults}

Length 13 to $17 \mathrm{~mm}$; width 5 to $7.5 \mathrm{~mm}$. Color dull brown, membrane darker; connexivum spotted in some, nearly concolorous in other specimens. Pronotum with anterior part of lateral margins finely and irregularly toothed. Humeri prominent but not spined. Hind femora swollen, especially in males, and with spines underneath, tubercles above.

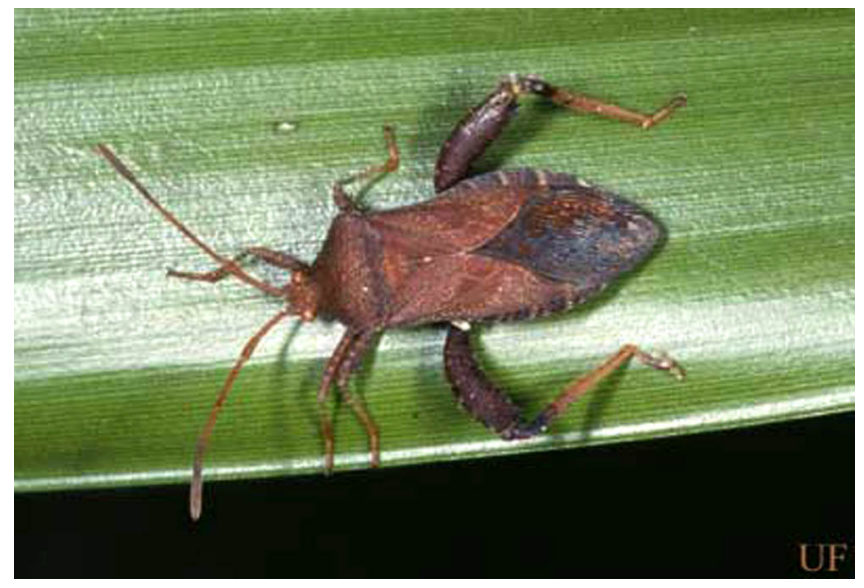

Figure 3. Adult Euthochtha galeator (Fabricius), a leaf-footed bug. Credits: Lyle J. Buss, University of Florida

\section{Special Character}

Males have a white- or cream-colored spur or flap on the posterodorsal corner of the side of the thorax (metepimeron) next to the abdomen. This easily is spotted in the field. No other known insect in eastern U.S. has such a projection. The females lack this flap but do have a whitish callus in the metapleural area. For a more complete description of the adult see Blatchley (1926) or Deay (1928). Consult Blatchley (1926), Schaeffer (1965), and Torre-Bueno (1941) for keys to the pertinent subfamilies and tribes of Coreidae.

\section{Life History}

Yonke and Medler (1969a) reported that eggs took about 13 days to incubate, nymphal development was approximately 54 days, and adults were long lived; two adults collected from the field in June lived 204 and 212 days. Young nymphs frequently were observed in feeding aggregations. Adults were reported to feign death. Whenever disturbed they would either drop from the plant and 
remain motionless, or fly away quickly. Froeschner (1942) reported E. galeator as common in Missouri in low, moist, weedy sections of woods, but also in weedy fields.

Mating was observed in June. Adults were collected all year; hibernating forms were collected under bark and among fallen leaves and other debris. Nymphs were collected in June and early July. Hoffman (1975) reported two peaks in the collecting of adults in Virginia. The first peak (coming out of hibernation) was from late April to mid-June, the second from late August through September (the ones destined for hibernation). The FSCA has more records of adults in March than any other month, but reports were fairly evenly divided throughout the warmer months. Blatchley (1926) reported $E$. galeator on the foliage of shrubs and trees along the slopes of hills and borders of thickets and roadsides in Indiana. At Dunedin, Florida he reported it in spring most frequently on sedges and weeds along the margins of lakes and ponds.

\section{Economic Importance}

Hubbard (1885) reported that E. galeator "was a very common and often a very destructive insect" on oranges (citrus). Ebeling (1959) reported E. galeator as having caused defoliation of potted plants of lychee, Litchi chinensis Sonn. Griffiths and Thompson (1957) reported that in Florida E. galeator fed on tender succulent twigs of citrus causing them to wilt and die. This type of damage was noted on as high as $25 \%$ of the trees in a small block of citrus; affected twig tips would turn brown and might dieback as much as 6 inches. Based on records in FSCA, E. galeator is a persistent pest of dooryard roses. Undisturbed nymphs and adults tend to feed in one spot for many hours; the longer the feeding the more pronounced the resulting injury. This injury seems to be caused by the injection of toxic substances, probably enzymes, into the plant tissue.

\section{Survey and Detection}

Look for a patch of golden-colored eggs on either surface of a leaf; detach leaf and submit in pillbox or plastic bag. Look for spiny nymphs, having dilated 3rd antennal segment, on succulent stem near cluster of terminal young leaves. Look for brownish,

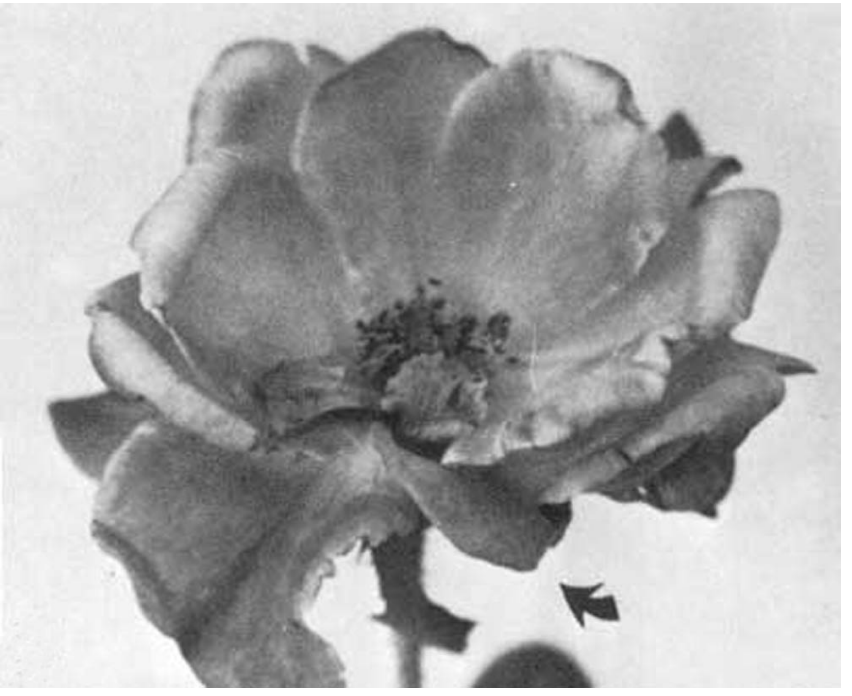

Figure 4. A rose blossom showing uneven development caused by feeding of Euthochtha galeator (Fabricius), a leaf-footed bug. Credits: Division of Plant Industry

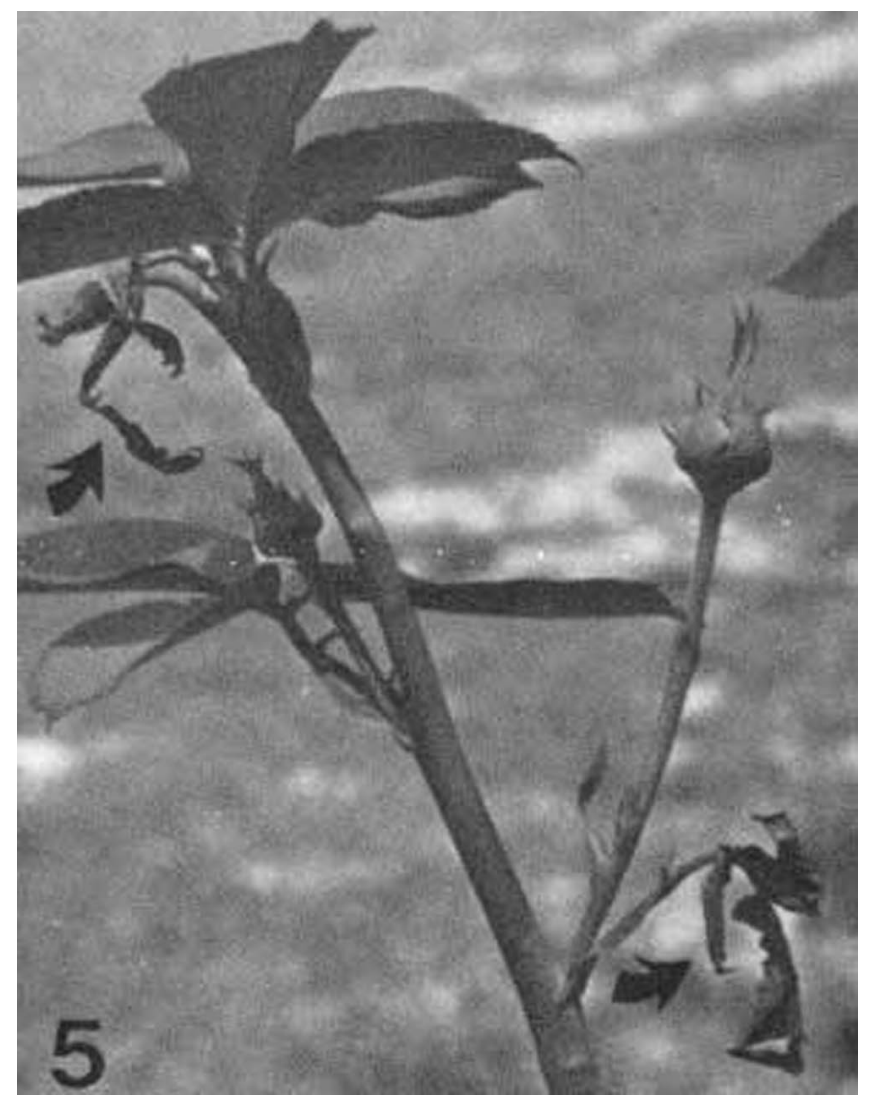

Figure 5. Wilting and withering of young rose leaves resulting from feeding by Euthochtha galeator (Fabricius), a leaf-footed bug. Credits: Division of Plant Industry

stout-bodied adults (16 mm long, $6 \mathrm{~mm}$ wide) on young stems, foliage or buds. Place nymphs and adults in vial of $70 \%$ isopropyl alcohol for submission to entomology for identification. 


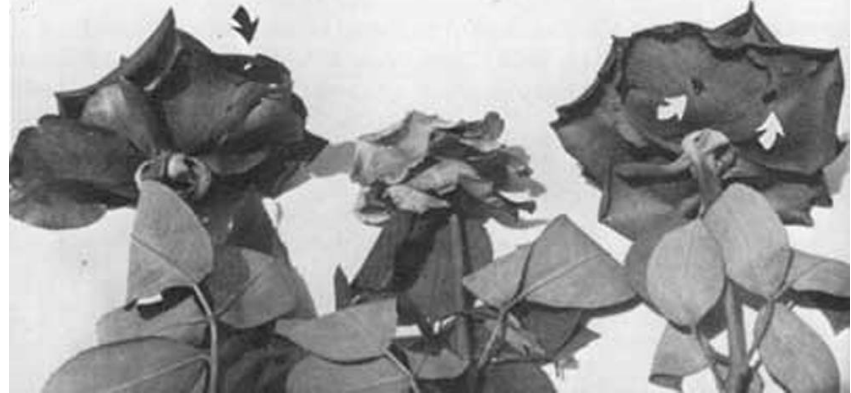

Figure 6. Larger rose blossoms, showing punctures and smaller blossom of a different variety partially distorted by feeding injury caused when bud was fed on by Euthochtha galeator (Fabricius), a leaf-footed bug. Credits: Division of Plant Industry

Most likely cultivated host plants are roses and to a lesser extent fruits, such as citrus and lychee. Wild hosts include composites, wild plums, polygala, grasses, sedges, nettles, sumac, young growth of hickory and oak, mint, etc.

Look for host damage caused by feeding of $E$. galeator. Blossoms become malformed; young leaves become droopy, withered, and brownish.

It should be possible to collect E. galeator in any Florida county.

\section{Management}

\section{Chemical}

If chemical control is used be especially careful to follow directions on label if fruits or other edibles are sprayed. Commercial plantings undergoing regular treatment for other insects seldom have a problem with this bug.

For more information see:

Florida Citrus Pest Management Guide for plant bugs (http://edis.ifas.ufl.edu/CG005)

Insect Management Guide for Landscape Plants (http://edis.ifas.ufl.edu/IG013).

\section{Biological}

Yonke and Medler (1969a) reported in Wisconsin two hymenopterous egg parasites, [Anastatus pearsalli Ashmead and Ooencyrtus anasae (Ashmead)] and a tachinid fly, [Trichopoda pennipes
(Fabricius)] that attacks adults. The latter two species are known to be in Florida.

\section{Selected References}

Blatchley WS. 1926. Heteroptera or True Bugs of Eastern North America, with Especial Reference to the Faunas of Indiana and Florida. Nature Publishing Company, Indianapolis, Indiana, 1116 p.

Deay HO. 1928. The Coreidae of Kansas. University of Kansas Science Bulletin 18: 371- 415.

Ebeling W. 1959. Subtropical fruit pests. University of California, Division of Agricultural Sciences, Los Angeles, California. 436 p.

Froeschner RC. 1942. Contributions to a synopsis of the Hemiptera of Missouri, Pt. II. American Midland Naturalist 27: 591-609.

Griffiths JT, Thompson WL. 1957. Insects and mites found on Florida citrus. University of Florida Agricultural Experiment Station Bulletin 591: 1-86.

Hoffman RL. 1975. The insects of Virginia: No. 9. Squash, broad-headed, and scentless plant bugs of Virginia (Hemiptera: Coreoidea: Coreidae, Alydidae, Rhopalidae). Research Division Bulletin 105, Virginia Polytechnic Institute \& State University, Blacksburg, Virginia. 52 p.

Hubbard HG. 1885. Insects Affecting the Orange. U.S. Department of Agriculture, Division of Entomology, 48th Congress, 2nd Session, House of Representatives, Miscellaneous Document No. 40, U.S. Government Printing Office, Washington, D.C. $227 \mathrm{p}$.

Schaeffer CW. 1965. The morphology and higher classification of the Coreoidea (HemipteraHeteroptera). Part III. The families Rhopalidae, Alydidae, and Coreidae. Miscellaneous . Publications of the Entomological Society of America: 1-76.

Slater JA, Baranowski RM. 1978. How to Know the True Bugs (Hemiptera- Heteroptera). The Picture Key Nature Series, W.C. Brown Co., Dubuque, Iowa. $256 \mathrm{p}$. 
Torre-Bueno JR. de la. 1941. A synopsis of the Hemiptera-Heteroptera of America north of Mexico.

Part II. Families Coreidae, Alydidae, Corizidae, Neididae, Pyrrhocoridae and Thaumastotheriidae.

Ent. Amer. 21: 41-122.

Yonke TR, Medler JT. 1969(a). Biology of the Coreidae in Wisconsin. Wisconsin Academy of Scientific Arts \& Letters 57: 163-188.

Yonke TR, Medler JT. 1969(b). Description of immature stages of Coreidae. 1. Euthochtha galeator. Annals of the Entomological Society of America 62: 469-473. 